\title{
Plates for Slates: The impact of a school feeding programme on community representations of schools
}

\section{ORIGINAL CITATION WITH DOI}

Chauhan, A. (2014). Plates for slates: The impact of a school feeding programme on community representations of schools. International Journal of Educational Development. doi:10.1016/j.ijedudev.2014.07.013

This document is the author's final manuscript accepted version of the journal article, incorporating any revisions agreed during the peer review process. Some differences between this version and the published version may remain. 


\title{
Plates for Slates: The impact of a school feeding programme on community representations of schools
}

\begin{abstract}
Using the nationwide school-feeding programme-the Mid Day Meal Scheme (MDMS)in India as its anchor, this paper critically evaluates the use of schools as sites for discharging social policies. Data from semi structured interviews $(\mathrm{N}=26)$ and focus groups $(\mathrm{N}=8)$ conducted in a north Indian village provide evidence that the community distrusts the central and the regional governments and regards state run schools as deficient institutions. The paper argues that the MDMS, interpreted in such a social climate, had a noteworthy impact of the community representations of local schools. On the one hand it was represented as an evil governmental design to distract poor people from education and was completely rejected by many community members. Such representations, the paper argues, further erodes the faith of the community in state run schools. Data from the study also indicate a second representational outcome where the MDMS has contributed to a shift in community representations of schools from being a site for imparting education to that of an institution providing free meals. The paper concludes by identifying two critical considerations that need to inform the use of schools as the site of social policy: (a) the symbolic environments of meaning making which inform local interpretations of policy; and (b) the representational activity surrounding the local reception and interpretation of policies. The theory of Social Representations informs the arguments made in the paper.
\end{abstract}

Keywords: Mid-Day Meal Scheme (MDMS); School feeding programmes; Educating the poor; Community Perspectives; India; Social Representations

Traditionally, schools have been institutions responsible for imparting academic and social skills to pupils. However, as Jones (2006) notes, several national and international agencies like the United Nations Children's Emergency Funds (UNICEF) have a welldocumented history of using schools for policy initiatives. At the present time, schools around the world have become integral to planning and delivery of policy initiatives that target children and young adults with an increasing range of policies being designed around schools (social and emotional learning, Durlak, Weissberg, Dymnicki, Taylor, \& Schellinger, 2011; preventing smoking, Thomas \& Perera, 2013).

The state run schools in India are currently the prime sites of a centrally supported feeding programme called the Mid Day Meal Scheme (MDMS) which aims to improve the nutrition of children by providing free meals to pupils during the lunch hour. The MDMS in Indian school is unlike any other policy in terms of its size and outreach. It is the world's largest school feeding programme and operates through more than one million schools to reach 120 million children across the country every day (MHRD, 2013). This paper takes a constructivist turn in evaluating the impact of the MDMS in a rural community in India and seeks to critically examine the use of schools as the sites of social policies. 
The paper comes out of a project that sought to understand the meaning making activities among a poor village community in Bihar, northern India. The goal of the project was not to evaluate or study the MDMS in particular but to understand how the community makes sense of the widespread poverty and the healthcare and educational facilities available to them locally. It was in this process that MDMS emerged as a major anchor that defined how the participants negotiated their understanding of the state run schools in the village. Without questioning the relevance of policies like the MDMS, the paper argues that using schools as a site of social policy presents a problematic in environments marked with high levels of mistrust towards the government and where schools are considered to be poorly functioning. The paper presents an example where the MDMS policy contributed to the shifting of the community's perception of schools from being a site of learning to one that provides free meals-a participant eloquently summarised what many in the community believe to be the case with MDMS: 'the government has given us plates for slates'. The paper does not embody an essentialist critique of involving schools with social policies-it does hope, however, to initiate a critical discussion on the unintended consequence that some policies administered through schools can present.

\section{A COOK'S TOUR OF MDMS}

MDMS was launched in 1995 with the official stated purpose as "enhancing enrollment, retention and attendance and simultaneously improving nutritional levels among children" (MHRD, 2013). The implementation of the scheme was slow in the first six years until 2001 when it gained momentum through the intervention of the Supreme Court of India. In 2001, a Supreme Court of India directive sought to implement the scheme across all state schools by February 28, 2002. However, very few states could manage to introduce the provisions for cooked meals by the end of February 2002 and the Supreme Court revised its deadline to January 2005. However, a major impetus to MDMS came through mass mobilization and the launch of a significant protest campaign. April 9, 2002 was designated as the 'day of action' (Right to Food Campaign, 2005 , p. 29) when public resentment over disdainful treatment of the Supreme Court's directive took the form of protests across several states. Khera (2013) argues this to be a major catalyst in the subsequent implementation of Mid Day Meals in schools across India. ${ }^{1}$ As of this date, all 28 states and 7 union territories in India have provisions for MDMS in place.

The MDMS has been argued to have several positive outcomes for the target group of school going children and the local communities. Dreze and Goyal (2003) consider the programme to be a 'nutritionist's dream' (p.4673). The Supreme Court directive on the meals served at schools makes clear recommendations regarding the calorific and protein content of the food (Khera, 2013). Research evidence from randomized evaluation of nutritional benefits of the programme in Madhya Pradesh, India indicates that the programme has indeed helped reduce calorie, protein and iron deficiencies among children (Afridi, 2010). Such positive impact of school feeding has also been observed outside India in quasi-experimental studies which show improvements in the nutritional intake of children receiving meals at schools (Jacoby, 2002). However, with a prominent concern with the Indian MDMS remains about the quality of meals served in the schools.

1 A detailed account of the campaign towards the implementation of the MDMS and the Right to food Act can be accessed at http://www.righttofoodindia.org/links/articles_home.html 
Several works in past have observed that the food provided by the schools does not meet the recommended nutritional levels prescribed by the Supreme court (see Jain \& Shah, 2005; De \& Noronha, 2005; Afridi, 2005) and children have taken ill after consuming the meals (see Menon, 2003; Khan, 2006; Seth, 2005; Sharma, 2005). What is more, at the time of writing this paper, the MDMS has received widespread attention following the death of many children after consuming the mid-day meal at their school in Bihar (BBC, 2013).

The direct impact of the scheme on the educational attainment of the pupils is hard to ascertain. Research indicates that the MDMS has improved the enrolment and participation of children in schools, especially among girls that were out of school (Dreze \& Kingdon, 2001). However, the evidence of improvements in learning through school feeding programmes is mixed. Vermeersch and Kremer (2005) suggest that such gains can be noticed, yet they are more intimately linked to the availability of good teachers. Similarly, other works have noted such improvements only in children 11-14 years in age (Adelman, Alderman, Gilligan, \& Lehrer, 2008). Critics of the scheme also argue that serving meals at schools disrupts teaching (Khera, 2013) and Blue (2005) reports from his work in Rajasthan, India that older students often help in cooking. Despite such observations, it would be incorrect to label this scheme as disruptive because it has been argued that the provision of afternoon meals within schools can prevent the often-noted phenomenon of students not returning to schools when they go home for their lunch (Drèze \& Vivek, 2002).

In essence, the MDMS has grown steadily in the last few years to achieve a near universal presence across the country. A systematic review of its performance is not the aim of this article. Using the MDMS as an anchor, the present work seeks to illustrate the importance of considering the impact social policies can have on the representations of schools in communities and how these representational dynamics may influence the very outcome the said policies.

\section{BACKGROUND TO THE STUDY}

The research was conducted in the village of Bholi ${ }^{2}$ in the state of Bihar, India. Bihar is a landlocked state divided into 38 districts and shares the international border with Nepal. Bholi is a flood stricken village along the international border with Nepal, about 150 kilometres from the state capital Patna, in a region which is recognised as the most underdeveloped part of Bihar (Mehta, Shah, \& Kapur Mehta, 2003). The most recent national poverty assessment exercise gives Bihar the unfortunate distinction of being one of the poorest Indian state: more than half of its population $(53.5 \%)$ lives under the official national poverty line (Government of India, 2012). It is also among the poorest faring state of India on the Human Development Index (Ghosh, 2011). Compared to the national average, the state has higher infant mortality rates, lower average life expectancy at birth, and lower literacy rates for both males and females (Government of Bihar, 2012). It has an average literacy rate of 63.82 percent-male literacy at 73.39 percent is better than female literacy rate of 53.33 percent. Table 1 clearly indicates how far Bihar lags from the rest of India with respect to basic school provisions.

\footnotetext{
2 Pseudonym adopted for the village for the rest of the paper. A majority of informants expressed their desire for personal as well as village's anonymity.
} 
Table 1: A comparison of Bihar with National average on basic school amenities

\begin{tabular}{|c|c|c|c|c|c|c|c|c|c|c|}
\hline & \multirow{2}{*}{\multicolumn{2}{|c|}{$\begin{array}{c}\text { \% of schools } \\
\text { complying with } \\
\text { the recommended } \\
\text { Student teacher } \\
\text { Ratio }\end{array}$}} & \multicolumn{8}{|c|}{$\%$ of Schools that have } \\
\hline & & & \multicolumn{2}{|c|}{ Playground } & \multicolumn{2}{|c|}{ Fence } & \multicolumn{2}{|c|}{$\begin{array}{l}\text { Drinking } \\
\text { Water }\end{array}$} & \multicolumn{2}{|c|}{ Toilet } \\
\hline & 2010 & 2012 & 2010 & 2012 & 2010 & 2012 & 2010 & 2012 & 2010 & 2012 \\
\hline Bihar & 8.8 & 8.5 & 48.3 & 43.1 & 48.1 & 47.9 & 78.7 & 85.9 & 33.6 & 51.2 \\
\hline India & 38.9 & 42.8 & 62.0 & 61.1 & 51.0 & 54.7 & 72.7 & 73.0 & 47.2 & 56.5 \\
\hline
\end{tabular}

Source: ASER (2012)

Given the high levels of poverty, thriving educational institutions and well-functioning schools are critical to the development of Bihar. Education is vital in the fight against poverty as it enhances the capabilities of the individual and allows an increasing assertion of basic rights among the poor (Govinda, 2003). Despite the tremendous role that education can play in extinguishing poverty, research indicates that the poor remain the most marginalized group with regards to education (IIEP, 1999). Clearly, the MDMS can be a boon for poverty-ridden villages in Bihar. The promise of a free meal served to all children attending schools may reduce the burden on poor families. By making staying in school rewarding, the MDMS can make incremental additions to the incomes of graduating students-evidence suggests that primary education increases earnings by $75 \%$ and a secondary education enhances earning by $163 \%$ as compared to an individual with no education, even when factors such as experience, location, and gender are controlled for (World Bank, 2004). Further still, education also has tertiary advantages for the poor and is associated with several positive social and health outcomes for the poor (for e.g. see Gounder \& Xing, 2012; Wedgwood, 2007; Friedman, 2002). In essence, it may not be incorrect to regard the MDMS as a promising policy for poor families as it has the potential to improve both educational and nutritional attainment of children.

In recent years, India has made tremendous strides in making education a priority area of developmental thrust. In April 2010, the landmark Right to Education Act came into force which assures all children between the age of 6 and 14 of free and compulsory education (BBC, 2010). A tremendous battlefront in realizing this promise is to be fought in the rural areas of the country where despite very high enrolment rates, the proportion of out of school children has increased (ASER, 2013, p. 47). While attractive policy measures like the MDMS have contributed to bringing more children to school than ever before, it becomes imperative to assess the impact these schemes have on the outlook of rural communities towards education and state run schools. Recent research in rural India warns against the fallacy of assuming that education is homogenously considered as worthy of the prolonged investment of time and resources that it demands (Maertens, 2011). Hence, it is essential to reexamine such educational initiatives in light of the response that they evoke among the target communities. With such a backdrop, this study reached out to a poor village community in the northern state of Bihar and explored the representations of education in the community.

\section{THEORY AND METHODS}

The work adopts a constructionist position (see, Raskin, 2002) and believes that processes of interpretation and meaning making mediate human responses to social policies. Social Representations Theory (henceforth, SRT) provides a meta-theoretical 
framework within social psychology that can be used to understand 'how' communities interpret their social worlds and develop their knowledge system (Moscovici, 1990). In words of Moscovici (1976), representations are:

A system of values, ideas and practices with a twofold function: first, to establish an order which will enable individuals to orientate themselves in their material and social world and to master it; and secondly, to enable communication to take place among the members of a community by providing them with a code for social exchange and a code for naming and classifying unambiguously the various aspects of their world and their individual and group history. (p. xiii)

In that sense, representations can be understood as the looking glass through which communities make sense of their material and social world. Social representations are dynamic products of a group's attempts to develop an understanding of objects and events in their social world and these attempts are situated in the group's contextual history and existing system of knowledge (Jovchelovitch, 2007). With this theoretical background, the specific arguments of this paper are based on the following assumptions:

1. Communal understanding of social policies involve representational meaning making.

2. Like all forms of novelty, a new policy will be understood within the confinements of the prevailing knowledge system.

Human sense making is a complex affair and these assumptions have a direct impact on the way in which the problem is operationalized in this paper. As Moscovici (1988) argues, it is in the process of understanding objects and events in the social world that subjective and objective phenomena metamorphose. A social policy (MDMS in this instance) entails a set of assumptions and a set of explicit goals and in that sense, mimics a certain degree of objectivity ${ }^{3}$. On the other hand, its assimilation in the target community is a highly subjective affair and occurs within the confinements of the broader knowledge environment of the community. Let me illustrate this by considering a hypothetical school in Bholi before the MDMS was introduced. Pupils attending the school—or parents sending their children to the school—on any certain day can be argued to be primarily guided by a common representation of schools as institutions where children receive education. Here the school is the object being represented and a key feature of the representation is the activity of learning. The advent of the MDMS added a novel element to the idea of schools: schools were no longer institutions engaged only in scholastic activities, they also became a site where pupils-most of them from poor families-are to be provided with meals. In such circumstances, it is easy to consider the MDMS as a novel event as its introduction reformulated the traditional understanding of schools as a site where the only relevant event was of teachers teaching pupils. It is in these moments of novelty that prevailing representations are changed or new representations are developed (Moscovici, 2000). However, this moment of flux does not disregard the existing understanding; on the contrary, the novelty is understood in terms of what is already known. Bauer and Gaskell (1999) consider a tripartite

\footnotetext{
3 It is important to acknowledge that this objectivity itself is a false property. The goals of a policy can be argued to be a reflection of the representations that the policy makers have of the problem. In saying that the policy mimics objectivity, the intention is to draw attention towards the monolithic approach to policy design and implementation where it is assumed that any given policy will be understood and 'used' by the target communities in a similar fashion.
} 
relationship to be relevant here: a relationship that involves the people that engage with representations; the object that is being represented; and the project or the pragmatic context in which these representations make sense. Indeed, the knowledge context of Bholi is of prime importance in deriving the arguments of this paper and this will be taken up at length in the next section. At this juncture, it is important to reiterate that this paper is not concerned with the representations of the MDMS in Bholi but looks to establish the impact it may have had on the representations of schools and it is hoped that the paper will be read in that light. In short, the goals of this paper are the following:

1. To demonstrate the relevance of the prevailing knowledge system in shaping a community's reception and response to a social policy

2. To demonstrate how non-scholastic social policies that use schools as their site of delivery can alter community representations of schools.

Data were collected during March and August 2013 in a village in the state of Bihar. Semi-structured interviews were conducted with 26 informants and 8 focus groups were organised with 31 participants. The study purposefully recruited informants of varied backgrounds and status in the community to capture the diverse range of opinions on the issue. Out of the total 55 informants who participated in the study, 42 identified themselves as poor and 13 did not think that they were living in poverty. All participants in the study had school going children in their families. In addition, 5 schoolteachers were also interviewed as key informants in the debate. The goal of the study was to understand how people made sense of education facilities and initiatives available in the village. Hence, participants were asked a broad question: What are the provisions/arrangements for education in this village? ${ }^{4}$ Further contextual probes were made depending on the nature of response of the participants. While talking about education in the village, every participant made a reference to the MDMS without the need of an explicit probe ${ }^{5}$. Finally, data were transcribed and analysed using the principles of thematic analysis (Boyatzis, 1998; Braun \& Clarke, 2006). The first stage of coding involved a process of systematic coding with an inductive approach-there were no pre-determined coding categories, yet, it is important to acknowledge that the theoretical position outlined above (SRT) informed the process of coding. After a thorough review, the open codes were coalesced into categories on the basis of similarity to eventually form thematic axes. Following Braun and Clarke (2006), in the present work themes represent "something important about the data in relation to the research question, and represents some level of patterned response or meaning within the data set" (p.10). Although all the themes developed during the analysis are well supported by a number of instances, no quantifiable criterion of repetition was taken into account. With its subscription to constructionist epistemology and qualitative research methodology, the work does not subscribe to the traditional notions of quantifiable indicators of reliability and validity. Yet, following Guba and Lincoln (1985) and Gaskell and Bauer (2000), indicators of quality (trustworthiness, rigour, transparency) were used as analogous ideas to reliability and validity.

The following section presents the three thematic axes that illuminate the reception and impact of the MDMS on the representations of schools in Bholi. The first two themes

\footnotetext{
${ }^{4}$ Approximate translation of the question: इस गाव में शिक्षा कि क्या व्यवस्था है?

5 The fact that MDMS appeared invariably in the participants' accounts is very meaningful and is picked upon in the discussion.
} 
provide the context within which the representational impact of MDMS develops and should therefore be read as the background to the main agenda.

\section{REPRESENTING SCHOOL FEEDING LOCALLY}

As it was argued earlier, representations are shaped by the pragmatic context of the social group. Hence, in order to understand the representational impact the newly introduced policy had on the community, it is essential to appreciate the context in which the novelty of the policy was negotiated with. Data collected at Bholi reveal that with regards to the MDMS, the context is predominantly defined by two issues. First, that it was a government initiative and this makes people's representations of the government relevant. Second, it was a policy that operated with schools as its primary site. The representational context along these two domains is elaborated below as the background in which MDMS was assimilated in the local community.

\section{An environment of mistrust}

Participants' accounts in Bholi reveal that a high degree of distrust marked the representations of government in the community. A general disappointment with the government machinery prevailed in the community and government institutions were regularly described as corrupt, exploitative and apathetic. ${ }^{6}$ A participant captures this in his description of a typical interaction between a petty bureaucrat and a poor person:

The world is such that without bribes you cannot do anything around here. No one ever comes here to ask if things work. No government official ever comes. If a poor man goes to meet the BDO (Block Development Officer) to tell him that he hasn't received his [welfare] cheque, he gets scolded and scoffed at. The BDO summons his peons and has the man shoved out of the office.

(Parent, BPL)

The seemingly deep rooted distrust of the government machinery was even more pronounced in the context of educational initiatives of the government. This scepticism emanates from the perceived belief that several governments in past have failed to take up the agenda of education. A participant described his frustration in the following way:

The situation is that teachers come [to the school] or they don't depending on their own mood. Governments keep changing: Lalu [Prasad Yadav] came, Nitish [Kumar] came, Indira [Gandhi] was removed-Indira eventually died too-now they talk of Sonia [Gandhi]. Administrations kept changing and now we have Nitish [Kumar] who has completely destroyed education. (Parent, BPL)

Participants also feel that the government plays an active role in disrupting the scholastic activities of the schools in village. They voiced their unhappiness over the manner in which school teachers are used on governmental censuses and surveys while classes remain disengaged.

\footnotetext{
${ }^{6}$ Governance in India is two tiered. There is a central government that looks after the country as a whole while each constituent state (province) has its own government. The accounts of participants made no distinction between the two-participant switched between making references to both the levels and in that sense, their use of the work 'government' should be considered as an instance of conflation, indicative of its symbolic nature.
} 
There are one or two teachers who are knowledgeable but they are often sent by the government to run errands. The government needs a survey in the village; they would put schoolteachers on it. (Parent, APL, Focus Group)

Even if there were only four teachers deputed at the school, the government would send two teachers away on tasks. "Go count the dogs, count the [incomprehensible], count the cattle in the village". That is how they make use of them. They are paid uselessly. (Parent, BPL)

Further still, the community was suspicious of the recent sense of urgency that the government has demonstrated. While the current government in Bihar has recruited a large number of new teachers in government schools on contractual basis, participants feel that this was done without any consideration whether right people were selected for the job. Instead of trying to strengthen the educational infrastructure, the government is believed to have negotiated a popular move through mass recruitment. A school teacher voices this sentiment as follows:

In my understanding, the government is not interested in education. They are interested only in getting votes-especially the present government has not recruited teachers, they have given employment. They haven't found teachers for schools; they have given employment to all the women and unemployed who were sitting idle in villages. We don't consider them teachers and even ministers in the government have said that they [new teacher recruits] may not have received a decent salary but the government has at least given them employment.

To sum up, the accounts given by the villagers indicates a strong lack of trust towards the government which is not only considered to be apathetic to the needs of the village but is also regarded as using educational policies as means to political ends. As I shall argue later, this mistrust coupled with the novelty that MDMS brought along, plays a critical role in the eventual impact of the policy. But before doing that, it is important to understand the second aspect of the social context of education and government schools in Bholi.

\section{Government schools as deficient}

A strong notion of government schools as deficient educational systems prevails in Bholi. This notion of deficiency takes several forms - the most common being the idea that little teaching takes place at government schools. All the informants in this study expressed their dissatisfaction with the quality of teaching available at government schools.

But these days in which government school do they teach? Nowhere. I have arranged for private coaching for my children and thanks to that they can at least read alphabets. (Parent, BPL)

Owing to this homogenous opinion of government schools, home tuitions are extremely popular in Bholi. They are conceived as the compensatory remedy for the deficient academic progress of pupils in government schools. An APL informant who sends his children for tuition classes explained the situation in the following fashion:

So most parents that want to educate their children send them to private tutors. What else can they do? There are 4-5 educated young men in the village who teach tuition 
classes. Others who can afford to pay 500 rupees (around \$10) choose private schools. (Parent, APL)

These tuitions are privately arranged and despite not being very expensive (average charges in the village ranged from $\$ 2.00$ to $\$ 3.00$ for 30 days of tuition to primary classes), poor families find it very difficult to consistently hire the services of a tutor. Not surprisingly, despite unanimously valuing the role of education, most families hold a depressive outlook towards the future of their children. A poor father who has been forced to leave the village and now works in Mumbai on daily wages describes his helplessness as follows:

I have 5 children. I want them to get educated and I want them to study here [at the government schools in the village] so that I don't have to pay. But I see that there is no education here. I sent them here [at the government schools in the village] but saw that they did not learn anything so I now send them to study privately. I really want them to get good education. But my economic situation is such that don't think I would be able to educate them for long. I have 4 daughters and a boy-when I see the children of welloff families who have got good education, I dream that my children too become like them and get a good name for me. But it doesn't seem that I can ever make that happen. (Parent, BPL, Focus Group).

In considering government schools as deficient, participants draw heavily from the real or perceived incompetence of teachers at the government schools. Many believed that most school teachers are themselves ill qualified to teach their classes. The following two quotes not only demonstrate the perceived incompetence of teachers but also further highlight the lack of trust Bholi has in the state government.

But Nitish Kumar [Chief Mister, Bihar] has recruited such incompetent teachers that if they manage to write their names on a piece of paper, I would be mighty impressed. If such people are teachers, what would happen to us and our children? (Parent, APL)

However, there are two schools in our village-one teaches until grade 5 and the second one until grade 8 . In the first school there are two female teachers who cannot write their names properly. This is the gift of Bihar government. The second school is until $8^{\text {th }}$ grade. It has two good teachers and the remaining 2 are just the same-utterly useless. (Parent, BPL).

To conclude, the pragmatic context in which MDMS was assimilated in the local knowledge system is marked by a lack of trust towards the government and a perceived deficiency in the government schools. As it was outlined at the start, these are critical with respect to the way MDMS was understood by the Bholi community as it was a government policy operating at government schools.

\section{The impact of MDMS on community representations of schools}

The previous segments describe the representations that participants had towards the government and the education system in the village. These generally negative representations form the context in which the MDMS appeared as a school-oriented policy initiative by the government. Data from this study suggest that the policy was received with a range of emotions ranging from complete opposition to a sense of acquiesced surrender. While there was a general sense of disenchantment with the state of educational activities in the government schools, the MDMS was considered to have destroyed whatever little scholastic activities that remained. 
There are no teaching activities left in school. Schools have become defunct since MDMS started. Since mid-day meals have started, the academic environment of schools has vanished completely. (Parent, APL)

This feeling was shared not only by the parents in the village but also by the teachers working in the schools. A teacher, who played a key role in establishing a middle school in the village 15 years ago, was very clear in his evaluation of the impact of the MDMS on the school.

Interviewer: What difference has it [MDMS] made?

Teacher: It has increased the numbers-the student who would have never come to school have started coming. But this scheme has damaged education irreparably.

The accounts from Bholi residents further suggest that the prevailing environment of mistrust with the government contributes to the dissatisfaction and opposition of the feeding programme. An excerpt from a retired school teacher who now lives in the village illustrates how most people in the community hold the government responsible for the damage that the MDMS has caused to the system of schooling in the village. :

Interviewer: What do you think of MDMS? What impact has it had?

Informant: Stop! I have been associated with the education department. I have seen my village and the whole of Jharkhand. [...]. The government is damaging the education system. This MDMS is the government damaging education. (Parent, APL)

In his opinion, the feeding programme appears to be the embodiment of the government's active design to damage the educational setup of state run schools. This representation finds an even more vivid description in the accounts of several other participants. People believed that the scheme is a distraction planned by the government to shift the attention of the poor away from learning at schools-the MDMS kept teachers, schools and children preoccupied with the business of feeding while the children from poor families, families that depend on the free government schools for educating their children, remain devoid of good education.

I think that wherever the Indian government finds money for this scheme [MDMS], whether from international sources or its own funds...the way the Nepalese government wanted to keep its citizens deprived of education...our government has adopted the same policy [of keeping us deprived of education]. It doesn't consider us villagers and poor peasants more than a dog. What does a dog need? A little bread or a small chunk of meat? If the dog is noisy and barks a lot, give it a piece of meat-it would stay occupied with it. I think the government runs this scheme to create opportunities for corruption and siphoning off the nation's money. (Parent, APL)

My opinion is that the present [educational] policies serve them [the government] well as they actively keep us uneducated and foolish. They have already done that to the current generation and they will do the same with future generations. They promise that they are giving a lot of attention to education but in reality, they are simply cheating us through their policies. (Teacher, 36)

In the quotes cited above, it is easy to see how the community appraisals of MDMS are guided by the general distrust of the government. As a result the MDMS is reconstructed in community representations as a direct attempt of the government to harm the village. Such representations indicate a strong likelihood of complete rejection of the policy 
among those who share the representation. However, as mentioned before, several participants had a less severe response towards the MDMS. While they too voiced their unhappiness with the school feeding scheme, their perspective on the MDMS was utilitarian. In Bholi few consider the government schools as good places for quality education. Accounts of several parents in this study suggest that they simply chose to see the MDMS as an opportunity for their children to get free food, notwithstanding the general belief that it has degraded scholastic activities in the schools. Take for example, the opinion of a relatively well-off man who gets his children taught privately, yet, sends them to the government school for the free meal. Here is what he had to say about the feeding programme:

So most parents who want to educate their children send them to private tutors. What else can they do? There are 4-5 educated young men in the village who teach. Others choose private schools. In government schools, we send our kids to have porridge. So they do that and come back. (Parent, APL)

Such representations of government schools appear to have no connection to scholastic activities-after all, this parent has hired private teacher for his children. Yet, the government schools are not completely irrelevant to people who share such representation. As the account of this parent suggests, they are happy that their children receive a free meal. While it is safe to say that before this scheme was introduced, the representations of government schools would not have had this element; examples such as these suggest a change in the way government schools are conceptualised in the community. It is also evident below, in a discursive context during an exchange with a parent:

Interviewer: How are the schools in this village?

Informant: They are all 'use and throw' [institutions]—-the one's that you would not like. My children sometimes bring back the meal they get at the school and it is rubbish. This is the story [of the schools]. Sometimes even that food is not provided.

Interviewer: What else can you tell me about them [schools]?

Informant: What else remains? They are completely useless.

(Parent, BPL)

This parent's notion of schools appears completely immersed in the feeding provisions that are supposed to be in place there. The quality of food served there is the sole criterion on which he chose to talk about the schools. While it is impossible to say with any degree of confidence that meals have become the most prominent element in the representations of schools, it is clear that teaching activities seem to have lost their prominence. This growing centrality of meals in the representations of parents becomes further evident in an exchange with a man who feels that his daughter-in-law is keen on ensuring that the children in the family carry plates and cutlery to school but never checks if they carry notebooks and stationary. Interestingly, his account of the MDMS links everything back to the prevailing dissatisfaction with the government. He holds the government responsible for the degradation of education and rather poetically accuses the government for giving the children plates instead of slates.

Participant: I strongly oppose the Mid Day Meal Scheme.

Interviewer: You oppose it?

Participant: Yes. 
Interviewer: Why do you oppose it?

Participant: I oppose it because in my house...My daughter in law, her perceptions have changed. She would forget books, she would forget the stationery but she would never forget my granddaughter's lunch plate. That she would place in the school bag with her own hands and say, "If you don't carry your plate, how would you eat?" She never says, "If you don't carry books and stationery, how would you study?" But she always says "If you don't carry your plate, how would you eat?" The government has given us plates for slates. (Parent, BPL)

This suspicion of the growing centrality of meals in the parents' representations finds further corroboration in the accounts of the headteacher of one of the government schools. She reports that parents seldom show any interest in meeting the teachers to speak about the academic progress of their wards and would largely remain unconcerned as long as the meals are being provided at schools. Only when there are disruptions with the MDMS, parents would come down to protest.

To some extent these parents are also responsible for the decline in education. They never take interest in finding out if their child is being taught at the school. It doesn't matter to them. They only come to the school to shout and protest about the meals not being tasty or if we fail to serve food for a day or two. That is all the business they have with this school these days.

What is more, one of the teachers, when asked about the feeding programme, spoke how it has taken a priority position even with local bureaucrats and administrators in the department of education. Here is what he had to say:

We go to meetings where officers come from the district. They tell us, "We don't tell you [the teachers] that you come to schools and teach. We tell you that you go to your schools and get the meals prepared and students fed." Now this is the problem. There [at the meetings] schools principals are never asked to worry about classroom teaching instead they are instructed to be attentive to the meals. These are the instructions of officers and people who handle education in this district. What do you expect from us?

So far, I have tried to demonstrate how the MDMS has contributed to a shift in representations of schools in the village in different quarters-parents, teachers, and bureaucrats. This creates a pertinent question: has it affected the way children in the village perceive their schools? While this study did not involve children and hence does not have any direct accounts to meaningfully answer that question, the narratives generated with parents and teachers provide some indirect evidence. Take for example the account of the same schoolteacher who was quoted earlier in the paper reporting that the MDMS has brought more students to school but has irreparably damaged school education. The conversation continues from the previous excerpt:

Interviewer: What difference has it made?

Informant: It has increased the numbers - the student who would have never come to school started coming. But this scheme has damaged education irreparably.

Interviewer: How so?

Informant: The reason was that children originally used to come to read. Now they come thinking that they are coming for a free meal. That is because the food is being cooked here. The most we can keep students at school is until midday. Food is cooked by then and the cook comes and tells us that food is ready. As soon as the pupils hear that the food is ready, then how hard we try, their mind is on food. They keep saying, "Sir, the food is ready!" Students are now more interested in food. 
Far from being an isolated observation, such descriptions of school-going children appeared in several accounts. Consider the following account of a parent who sends his children to private schools:

This arrangement of MDMS is an extremely damaging scheme because of which education has suffered tremendously. Children go to the school carrying steel plates and other cutlery from their homes and until the food is being cooked, they hold back and teachers do whatever they can. Once the food is served children do not go back to classes and play around for a while and then they come back home. (Parent, APL)

These instances suggest a possibility that the representations of school going children may have had an impact with the introduction of MDMS. It is not hard to appreciate if one reflects from the standpoint of children. In my numerous visits to the schools in village, I could see how the cooking of the meals was the showpiece event in the school. Every morning food was cooked in an open kitchen with generous involvement of the teachers and it was not unusual for children to stand and watch the proceedings with curiosity. Nevertheless, in absence of direct data from children, a commentary in this regard remains beyond the scope of this paper.

To sum up, two conclusions can be drawn about the representational activity surrounding the MDMS in Bholi. First, a general environment of mistrust with the government and disappointment with the government schools formed the broader context in which public reaction to the MDMS needs to be understood. Second, given the homogenous representation of government schools as defunct institutions, the introduction of MDMS seems to have resulted in a shift in the representation of these schools - the centrality of teaching and learning in representations of schools as institution seems to have been displaced to a certain degree by the idea that schools are institutions that provide free meals.. The following section discusses some of the implications of these findings and seeks to problematise the use of schools as sites of policies in environments resembling that of Bholi.

\section{USING SCHOOLS AS POLICY SITES: SOME IMPLICATIONS}

We understand the world through a web of representations and social policies are no different. Society makes any new object in the social or material world familiar by developing representations that aid the accommodation of novelty. This paper hopes to have demonstrated how the MDMS provided a moment of novelty in Bholi and how it was assimilated in the local knowledge system-the scheme met either utter rejection or an acquiesced acceptance but never a wholehearted embrace. In examining these representational dynamics, the present work brings several points of consideration with regards to implementing social policies through schools. In this section-with the MDMS in Bholi as an example-I would assert that from the standpoint of social psychology, two factors need careful consideration while using schools as the site of social policies, or indeed, with respect to social policies in general. The first aspect is of the symbolic environment in which social policies are received and understood whereas the second aspect is of the representational activity surrounding the local reception and interpretation of policies. I pick each of these for discussion below. 
MDMS in Bholi provides a clear example of the need to consider the symbolic environment of meaning making in which social policies operate. As this paper documents, the MDMS was a radical policy introduced in an environment marked by deficient levels of trust. On the face of it, a free and compulsory school feeding programme presents an opportunity to families, especially in the poorer parts of India, to improve both nutritional and scholastic attainment of children. Despite that, in Bholi we not only find an opposition but a deep rooted suspicion towards it. As this paper documents, such a public response to MDMS can be understood better by taking into account the social environment of Bholi. Research documents that moments of novelty that constitute a radical change in the traditional concept of an object are viewed with apprehensions (see for example, the reception of biotechnology in Wagner \& Kronberger, 2001). In Bholi, the novelty that MDMS brought to the concept of schools was further problematized by the existing belief of government schools as defunct institutions and a general mistrust towards the governments. Altogether, the set of circumstances lead the Bholi community-parents and teachers alike-to question the government and its motives behind the MDMS. In its extreme form, the resulting representational activity conceived the scheme as an active attempt to keep the poor distracted and deprived of education. It would perhaps be fair to say that such representations were neither expected, nor anticipated by people behind the idea of the MDMS, yet, they constitute a part of the local reception of the policy in a community. What is more, this representational conflict between the intended and the understood sides of the MDMS can lead to a functional collapse-left to the prevailing circumstances, the community continues to feel cheated by the policy and if the policy is discontinued to appease the discontent, a potentially useful initiative would lose its way.

The second insight emerges from the representational activity surrounding the MDMS. In addition to forming the basis of a community's knowledge system, social representations also embody the symbolic coping of a community with the perceived state of affairs. In that regard, the representations that people and communities construct are suggestive of the attempts to negotiate at the ideational level, the lived realities and experiences of everyday life (see, Wagner \& Kronberger, 2001; Wagner, 1998). In Bholi, there is a fracture between education as it is valued by people and the education that is available to them. On the one hand, the community is keen on education and regards it as a valuable capability; on the other hand, the material environment of schooling and education that the community is forced to live with is harsh, insensitive, and even exploitative. The data indicate that in the local socio-political dynamics, the MDMS and the agenda of schooling is being used to garner legitimacy and support by the government: the local bureaucrats are keen on the success of the MDMS even at the cost of teaching activities in schools and the political discourse brandishes appointing teachers as providing jobs to the unemployed. As the agenda of improving the scholastic attainment of students through the MDMS suffers, the meaning making activities in the community led to two distinct representational patterns.

Some members out rightly rejected the policy as an attempt on the part of the government to keep the poor uneducated and consider the policy to have 'irreparably damaged' the educational setup. In its extreme, participants sharing such representations see it as the proverbial bone thrown at the dog. Clearly, the prevailing climate of distrust with the government plays a critical role in the evolution of such representations. However, such representations of the MDMS are also a way of coping for the community with the harsh reality of deprived educational setup available to it, along with its generally depressive outlook towards the different tiers in government. The 
representational rejection of the MDMS in Bholi is also indicative of a greater rejection of the government-both as an institution and an agent of change. What is more, it also is an illustration of Bholi as an agentic community, a community that is not passive and apathetic towards education but instead seeks positive social change.

A second representational outcome of introduction of the MDMS is visible in the role that it seems to have played in altering the representations of schools and education in the Bholi community. Representational projects are dynamic and remain in a constant state of flux-new information leads to a reorganization/revision of the existing contents of representation (Bauer \& Gaskell, 1999). Prior to the provision of free meals, one may presume that the representations of schools were developed around the notions of learning whereas post MDMS there seems to be a growing tendency to associate schools more with the provision of free meals. Once the representation of an object undergoes a change, public orientation towards it follows suit. Not surprisingly, one finds accounts in Bholi that suggest that as long as free food is provided, parents no longer care about teaching. Policies like the MDMS can certainly contribute to improving the state of education as well as health in the poorer communities of India. However, if these policies inadvertently shift the notion of schools away from their primary goal of providing quality education to pupils, the potential gains from schemes such as MDMS become a matter of debate. This is one of the main points that this paper seeks to make. The use of schools in policy initiative has its unquestionable merit, especially if the target groups are children of school going age. But while conceiving and discharging these policies, it is essential to bear in mind the potential consequences they can have with regards to the very notion of schools. After all, will a school remain a school if the community no longer views it as an institution that should educate children?

In conclusion, it must be acknowledged that the implementation of social policies is a complex business, more so with centrally implemented policies which do not involve a mere relay of instructions from the center to the peripheries (Pressman \& Wildavsky, 1973). The actual implementation dynamics of any policy often has a local flavor and differs from one region to another even within the same country (Coleman, Checkland, Harrison, \& Hiroeh, 2010). However, the impact assessment of a social policy like MDMS is usually limited to interpreting certain tangible outcomes like increased attendance and gains in enrolment rates. The evidence from Bholi further reiterates the need for constructivist approaches to supplement policymakers' assessment of policies like the MDMS. This paper is an effort to present an illustrative commentary on this often-neglected, yet critical, need to consider the representational aspects of involving schools in policies. Taking a perspective rooted in local sensemaking, this paper has tried to underline the importance of understanding the representational ripples created when a social policy meets the turbulence beneath the surface of a local community's knowledge system. The representational upheaval, as Bholi bears testimony, can not only undermine the outcomes but also have detrimental consequences that never meet the eye or are caught on the tangible dimensions of assessment. Admittedly, the present paper neither seeks to, nor it can, provide solutions but it hopes to have demonstrated two crucial points with respect to using schools as policy sites: first, implementing a non-scholastic policy has the potential to shake the key idea that schools are centers of learning; and second, an environment of mistrust can severely influence the light in which target communities will view the policy initiatives. At the end, it is hoped that the paper succeeded in communicating that local sense making requires a detailed consideration and a careful negotiation for making even the most straightforward policies work. 


\section{ACKNOWLEDGEMENTS}

The paper comes from the doctoral research of the author which is generously funded by the London School of Economics \& Political Science (LSE) PhD Scholarship. The author would also like to thank Professor Catherine Campbell and the HCD research group, Nils Toepfer, and Surbhi Sehgal for their comments on previous drafts of this manuscript. The author would also like to thank two anonymous reviewers for providing helpful comments on the earlier drafts of the manuscript.

\section{BIBLIOGRAPHY}

Adelman, S., Alderman, H., Gilligan, D. O., \& Lehrer, K. (2008). The impact of alternative food for education programs on learning achievement and cognitive development in Northern Uganda. Unpublished Manuscript, University of Maryland, World Bank, International Food Policy Research Institute, and University of British Columbia.

Afridi, F. (2010). Child welfare programs and child nutrition: Evidence from a mandated school meal program in India. Journal of Development Economics, 92(2), 152-165.

ASER. (2013). Annual Status of Education Report (Rural) 2012. New Delhi.

Bauer, M., \& Gaskell, G. (2002). Biotechnology: The making of a global controversy. Cambridge: Cambridge University Press.

Bauer, M. W., \& Gaskell, G. (1999). Towards a paradigm for research on social representations. Journal for the Theory of Social, 29(2), 163-186. doi:10.1111/14685914.00096

Bauer, M. W., \& Gaskell, G. (2000). Qualitative researching with text, image and sound: A practical handbook for social research. London: Sage publications.

BBC. (2010). India launches children's right to education. Retrieved December 28, 2013, from http://news.bbc.co.uk/1/hi/8598167.stm

BBC. (2013). School meal kills 22 in India’s Bihar state. Retrieved May 17, 2014, from http://www.bbc.co.uk/news/world-asia-india-23337445

Blue, J. (2005). The Government Primary School Mid-day Meals Scheme: An Assessment of Programme Implementation and Impact in Udaipur District. Udaipur.

Boyatzis, R. E. (1998). Transforming Qualitative Information: Thematic Analysis and Code Development. Thousand Oaks, CA: Sage Publications.

Braun, V., \& Clarke, V. (2006). Using thematic analysis in psychology. Qualitative Research in Psychology, 3(2), 77-101.

Coleman, A., Checkland, K., Harrison, S., \& Hiroeh, U. (2010). Local histories and local sensemaking: a case of policy implementation in the English National Health Service. Policy \& Politics, 38(2), 289-306. doi:10.1332/030557309X462547 
DeSantis, L., \& Ugarriza, D. N. (2000). The Concept of Theme as Used in Qualitative Nursing Research. Western Journal of Nursing Research, 22(3), 351-372. doi:10.1177/019394590002200308

Dreze, J., \& Goyal, A. (2003). Future of Mid-Day Meals. Economic and Political Weekly, 4673-4683.

Drèze, J., Kingdon, G. G. G., \& Dreze, J. (2001). School participation in rural India. Review of Development Economics, 5(053660), 1-24. Retrieved from http://onlinelibrary.wiley.com/doi/10.1111/1467-9361.00103/abstract

Drèze, J., \& Vivek, S. (2002). Hunger in the Classroom. Food and Nutrition World.

Durlak, J. A., Weissberg, R. P., Dymnicki, A. B., Taylor, R. D., \& Schellinger, K. B. (2011). The impact of enhancing students' social and emotional learning: A metaanalysis of school- based universal interventions. Child Development, 82(1), 405-432.

Ghosh, G. (2011). Poverty, Inequality and Inclusive Growth: Cross State Analysis in India. Economic Affairs, 56(2), 161-167. Retrieved from http://www.ndpublisher.in/Last_Issue/EA/09_Economics.pdf

Gounder, R., \& Xing, Z. (2012). Impact of education and health on poverty reduction: Monetary and non-monetary evidence from Fiji. Economic Modelling, 29(3), 787-794. doi:10.1016/j.econmod.2012.01.018

Government of Bihar. (2012). State Profile. Retrieved December 01, 2012, from http://gov.bih.nic.in/Profile/default.htm

Government of India. (2012). Press Note on Poverty Estimates, 2009-10. New Delhi: Press Information Bureau.

Govinda, R. (2003). Making Basic Education Work for the Poor : Experiences from the South. IDS Bulletin, 34(1), 81-89.

Jacoby, H. G. (2002). IS THERE AN INTRAHOUSEHOLD "FLYPAPER EFFECT”? EVIDENCE FROM A SCHOOL FEEDING PROGRAMME. The Economic Journal, 112(476), 196-221. doi:10.1111/1468-0297.0j679

Jones, P. W. (2006). Elusive mandate: UNICEF and educational development. International Journal of Educational Development, 26(6), 591-604.

Jovchelovitch, S. (2007). Knowledge in context: Representations, community and culture. London: Routledge.

Khera, R. (2013). Mid-Day Meals in Primary Schools: Achievements and Challenges. Economic and Political Weekly, xlviiI(32), 4742-4750.

Lincoln, Y. S., \& Guba, E. G. (1985). Naturalistic Inquiry. Beaverly Hills: CA: Sage Publications. 
Maertens, A. (2011). Does Education Pay Off? Subjective Expectations on Education in Rural India. Economic and Political Weekly, 46(09), 58-63. Retrieved from http://www.epw.in/special-articles/does-education-pay-subjective-expectationseducation-rural-india.html

Mehta, A., Shah, A., \& Kapur Mehta, A. (2003). Chronic Poverty in India: Incidence, Causes and Policies. World Development, 31(3), 491-511. doi:10.1016/S0305750X $(02) 00212-7$

MHRD. (2013). About the Mid Day Meal Scheme. Retrieved August 31, 2013, from http://mdm.nic.in

Moscovici, S. (1976). La Psychanalyse: son image et son public. Paris: PUF (originally published in 1961).

Moscovici, S. (1988). Notes towards a description of social representations. European Journal of Social Psychology, 18, 211-250. Retrieved from http://onlinelibrary.wiley.com/doi/10.1002/ejsp.2420180303/abstract

Moscovici, S. (1990). Social Psychology and Developmental Psychology: Extending the conversation. In G. Duveen \& B. Lloyd (Eds.), Social Representations and the Development of Knowledge (pp. 164-185). Cambridge: Cambridge University Press.

Moscovici, S. (2000). The phenomenon of Social Representations. In G. Duveen (Ed.), Social Representations: Explorations in Social Psychology (pp. 18-77). Cambridge: Polity Press.

Pressman, J. L., \& Wildavsky, A. (1973). Implementation. Berkley, CA: University of California Press.

Raskin, J. (2002). Constructivism in psychology: Personal construct psychology, radical constructivism, and social constructionism. American Communication Journal, 5(3). Retrieved from http://digilander.libero.it/costruttivismi/raskin.pdf

Right to Food Campaign. (2005). Mid Day Meals: A primer. Retrieved August 31, 2013, from www.righttofoodindia.org/data/mdmprimer.doc

Thomas, R., \& Perera, R. (2013). School-based programmes for preventing smoking. Cochrane Database Syst Rev, 4.

Vermeersch, C., \& Kremer, M. (2005). School meals, educational achievement, and school competition: evidence from a randomized evaluation (Vol. 3523). World Bank Publications.

Wagner, W. (1998). Social representations and beyond: Brute facts, symbolic coping and domesticated worlds. Culture \& Psychology, 4(3), 297-329.

Wagner, W., \& Kronberger, N. (2001). Killer tomatoes! Collective symbolic coping with biotechnology. In K. Deaux \& G. Philogene (Eds.), Representations of the Social: Bridging Theoretical Traditions. Oxford: Blackwell. Retrieved from http://www.academia.edu/download/31017670/WagnerKrnbrgr_Deaux_2001.pdf 
Chauhan, A. (2014) Plates for Slates

Wedgwood, R. (2007). Education and poverty reduction in Tanzania. International Journal of Educational Development, 27(4), 383-396. doi:10.1016/j.ijedudev.2006.10.005 